ORIGINAL ARTICLE

AFRICAN JOURNAL OF CLINICAL AND EXPERIMENTAL MICROBIOLOGY JANUARY 2010

ISBN 1595-689X VOL 11(1)

AJCEM/2008139/21006

-http://www.ajol.info/journals/ajcem

COPYRIGHT 2010

AFR. J. CLN. EXPER. MICROBIOL 11(1): 129-136

\title{
BRANDS OF AMPICLOX AGAINST CLINICAL STRAINS OF STAPHYLOCOCCUS AUREUS
}

* Adeleke1, O.E., Coker1, M.E., Oluwagbohun², J.O. \& Fatoyinbo², A. D. Department of ${ }^{1}$ Pharmaceutical Microbiology, University of Ibadan, Nigeria, and 'Department of Microbiology, University of Agriculture, Abeokuta, Nigeria

RUNNING TITLE: AMPICLOX BRANDS AGAINST STAPHYLOCOCCUS AUREUS

* Correspondence: Department of Pharmaceutical Microbiology, University of Ibadan, Nigeria. E-mail: adelzek@yahoo.com GSM Phone: 08023896439

\begin{abstract}
Proliferation of different brands of antibiotics including ampiclox (a notable penicillinase inactivator) was considered a relevant factor in the antibiotic resistance of Staphylococcus aureus. Consequently the antibiogram and susceptibility of 20 clinical strains and a control strain (NCTC 6571) of Staphylococcus aureus to 10 different brands of ampiclox were determined by disk diffusion and tube broth dilution methods. The control strain was found sensitive to ampicilin, augmentin ${ }^{R}$ and cloxacillin in the antibiogram, and to all the 10 brands of ampiclox, with the MIC's of either 0.125 or $0.25 \mu \mathrm{g} / \mathrm{mI}$ among the clinical strains. This result, compared with the MIC's obtained in the range of $0.125 \mu \mathrm{g} / \mathrm{ml}$ to $>60 \mu g / \mathrm{mI}$, varying among the brands of ampiclox against the 20 clinical strains, indicates contrasting inhibitory activity among the different brands but reflective of the worrisome level of resistance to antibiotics by Staph. aureus. However, this resistance to most of the brands of ampic1ox could not be associated with brand variation having found the control strain sensitive to all the brands of ampiclox.
\end{abstract}

\section{INTRODUCTION}

Ampiclox is a Beta-lactam combination antibiotic comprising ampicillin (an aminobenzylpenicillin) and cloxacillin, both of which are still obtainable as individual penicillins. Ampicillin and cloxacillin represent an improvement over the parent penicillins (penicillin $\mathrm{G}$, penicillin $\mathrm{V}$ and benzathine penicillin) in terms of stability in the presence of the gastric juice acid and (Beta-1actam drug inactivating enzymes - penicillinase and cephalosporinase and spectrum of antimicrobial activity(1). Though

ampillin is susceptible to the action of (Beta-1actamase\{2), a deficiency that accounts for its combination with cloxacillin, thus producing a synergy in the antibacterial activity of ampiclox. However, there have been reports of multiple drug resistant staphylococci to antimicrobial agents $(3,4,5)$. In this episode of multiple drug resistance (MDR) ampicillin, amoxicillin and cloxacillin (6) as well as other Beta-lactamase targeted antibiotics like ampiclox have 
not been excluded: amoxicillinclavulanate, methicillin, vancomycin, and cephalosporins $(7,8,9,10,11,12,13)$. The MDR in Staphylococcus aureus has' been largely attributed to resistance genes borne on R-plasmid DNA(14). Notably, the hospital strains of this organism have been greatly implicated(15). Staph aureus is an important cause of community and hospital acquired infections $(16,17)$. Besides plasmid, high-level resistance could also occur from a low level through a multistep process due to chromosomal gene .alteration(18).

Among the enormous number of antibiotics avmlable, pencillin antibiotics are recognizably the most commonly used. This could explain the high level of production of these antibiotics in different forms-single, combination and different brands. Antibiotic prescribing has been observed to be in favour of some particular brands of antibiotics particularly, ampiclox(19). Hence, the need for this study to evaluate the antimicrobial potency of available different brands of ampiclox.

\section{MATERIALS AND METHODS \\ BACTERIOLOGY}

Strains of Staphylococcus aureus from different clinical sources, numbering 20, were collected from the Medical Microbiology Laboratory, University
College Hospital (U.C.H.), Ibadan and General Bacteriology Laboratory, Lagos University Teaching Hospital (LUTH), Lagos, Nigeria (Table 1). All the clinical strains were screened for purity by means of some coagulase test with reference to a control preserved on Nutrient agar (OXOID) slants at $4^{\circ} \mathrm{C}$ in a refrigerator until when they were needed.

\section{ANTIBIOTICS}

Ten brands of ampiclox (powder for injection) were purchased from local pharmacy shops, and given codes as : EL, PH, JA, CL, ML, RS, SK, RH, TR.

Antibiotic Disks (Abtek Biological Ltd.): Augmentin ${ }^{R}$ \{30 $\mu$ g), Amoxicillin $(25 \mu \mathrm{g}), \quad$ Erythromycin $\quad(5 \mu \mathrm{g})$, Tetracycline (10 $\mu \mathrm{g})$, Cotrimoxazole $(25 \mu \mathrm{g}), \quad$ Chloramphenicol $\quad(30 \mu \mathrm{g})$, Cloxacillin $(5 \mu \mathrm{g})$, Gentamicin $(10 \mu \mathrm{g})$.

\section{ANTIBIOGRAM}

The antibiotic susceptibility pattern of each strain of Staph. aureus was determined by the Kirby-Bauer's DiskDiffusion method as previously described(21). The inoculum size of each strain was $10^{7}$ cells $/ \mathrm{ml}$ in O.lml taken from $10^{2}$ dilution of overnight broth culture, as determined in a pourplate culture. All the culture and sensitivity plates were incubated at $37^{\circ} \mathrm{C}$ for $24 \mathrm{hrs}$. Zones of growth inhibition were then observed and measured in millimeters $(\mathrm{mm})$ to 
determine sensitivity or resistance to a particular antibiotic disc (Table 2).

MINIMUM

INHIBITORY

CONCENTRATIONS (MIC) OF THE BRANDS OF AMPICLOX

The tube-broth dilution method was used to determine MIC. Suitable high aq. stock concentrations of each brand of ampiclox were prepared to provide $60,50,20$, and $4 \mu \mathrm{g} / \mathrm{rnl}$, in four different tubes of $10 \mathrm{ml}$ nutrient broth (OXOD) each. Serial dilutions were made also in nutrient broth to give the following antibiotic concentrations: 30, $25,10,4,2,1,0.5,0.25,0.125,0.0625$ and $0.031 \mu \mathrm{g} / \mathrm{m} 1$. Each dilution was then inoculated with O.1ml from 10-2 aq. dilution (equivalent to $10^{7}$ cells $/ \mathrm{ml}$ ) of an overnight broth culture. The mixtures were then incubated at $37^{\circ} \mathrm{C}$ for $24 \mathrm{hrs}$, followed by observation for sensitivity or resistance revealed by the visibility of turbidity in each tube to determine the MIC.

\section{RESULTS}

In the antibiogram for the clinical strains of Staph aureus, amoxicillin, augmentin $^{R} \quad$ (amoxicillin-clavulanate) and cloxacillin showed no zone of growth inhibition, but did so for the control strain, NCfC 6571. Gentamicin and chloraphenicol were relatively outstanding in their antistaphylococcal activity (Table 2). Among the 10 brands of ampiclox, 9 brands exhibited reasonable activity of MIC $0.125-0.5 \mu \mathrm{g} / \mathrm{ml}$ (Table 3) against 9 of the clinical strains (i.e. $45 \%$ ) of Staph. aureus at different levels: $\mathrm{BH}$ (5 strains), SK (2 strains), TR (1 strain) RH (1 strain) and CL (4 strains). Thus, one coded EL lacked activity against any one of the clinical strains. These variations are reflected as percentage resistant pattern of the clinical strains (Table 4). However, everyone of the ampiclox brands produced MIC of either $0.125 \mu \mathrm{g} / \mathrm{ml}$ or $0.25 \mu \mathrm{g} / \mathrm{ml}$ against the control strain of Staph. aureus, NCfC 6571 (Table 3). 
TABLE 1: THE CLINICAL STRAINS OF STAPHYLOCOCCUS AUREUS

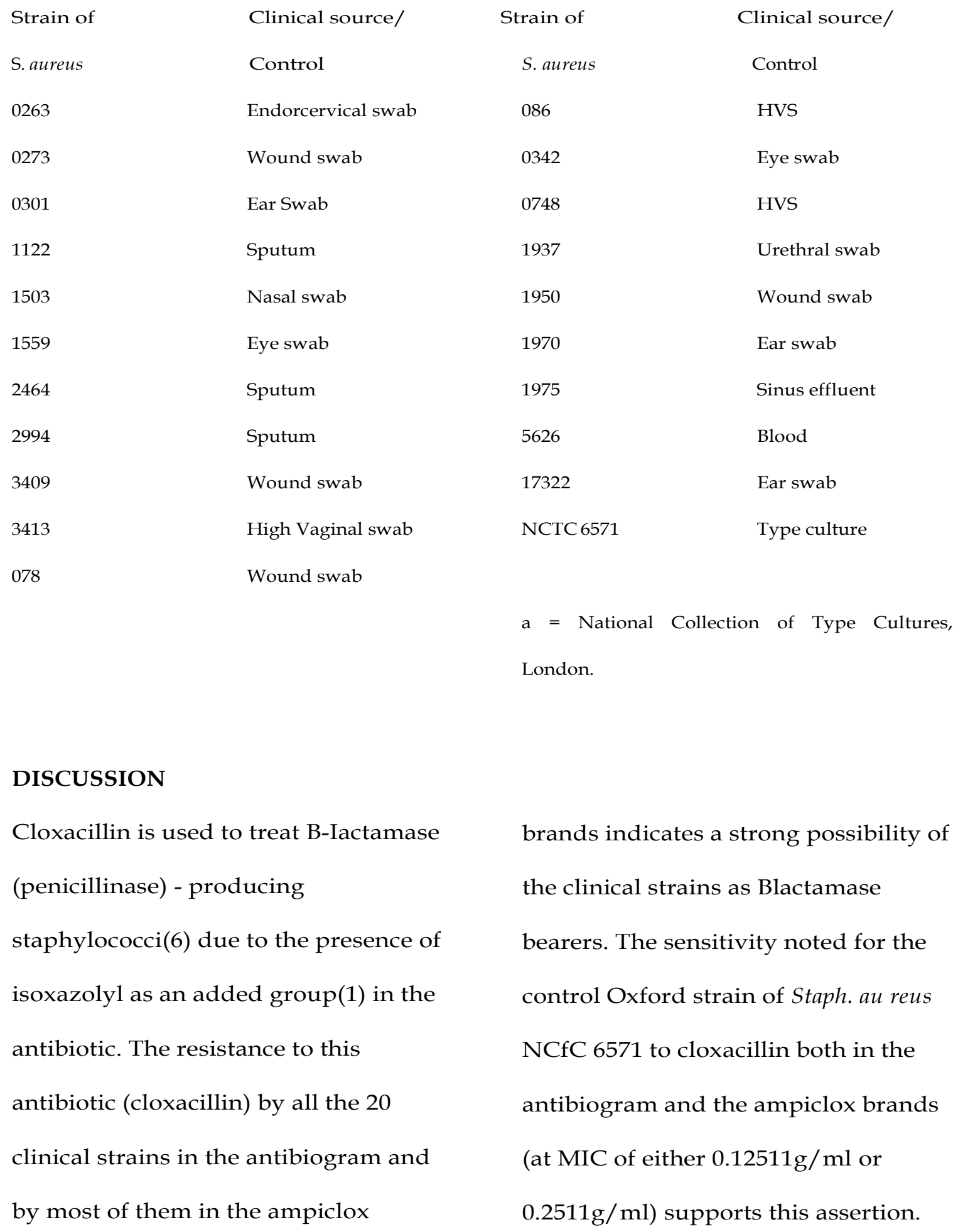


TABLE 2: ANTIBIOGRAM OF THE CONTROL NCTC 6571 AND CLINICAL STRAINS OF STAPHYLOCOCCUS AUREUS

\begin{tabular}{|c|c|c|c|c|c|c|c|c|}
\hline & & & & \multicolumn{5}{|c|}{ Antibiotic disk( $\mu . g)$} \\
\hline & Aug & $\operatorname{Amx}$ & Ery & Tet & CXc & Gen & Cot & ChI \\
\hline S.aureus & & & & & & & & \\
\hline NCTC & $20.0^{*}$ & 18.0 & 22.2 & 25.5 & 21.5 & 23.1 & 6.4 & 14.0 \\
\hline 078 & $* *_{-}$ & - & - & - & - & - & - & - \\
\hline 086 & - & - & - & - & - & 17 & - & - \\
\hline 0342 & - & - & - & - & - & - & - & - \\
\hline 0748 & - & - & - & - & - & - & - & - \\
\hline 1937 & - & - & - & - & $\begin{array}{l}- \\
\text { 'i }\end{array}$ & 16 & - & - \\
\hline 1950 & - & - & - & - & - & 17 & - & 15 \\
\hline 1970 & - & - & - & - & - & 15 & - & - \\
\hline 1975 & - & - & - & - & - & 23 & 22 & 25 \\
\hline 5626 & - & - & - & - & - & - & - & - \\
\hline 17322 & - & - & - & - & - & - & - & 10 \\
\hline 0263 & - & - & - & - & - & 16 & - & - \\
\hline 0273 & - & - & - & - & - & 15 & - & - \\
\hline 0301 & - & - & - & - & - & 13 & - & - \\
\hline 1122 & - & - & - & - & - & - & - & - \\
\hline 1503 & - & - & - & - & - & 12 & 10 & 10 \\
\hline 1559 & - & - & - & - & - & 17 & 12 & 11 \\
\hline 2464 & - & - & - & - & - & 24 & 22 & 18 \\
\hline 2994 & - & - & - & - & - & 12 & 10 & 9.0 \\
\hline 3409 & - & - & - & - & - & 13 & 11 & 10 \\
\hline 3413 & - & - & - & - & - & 21 & 15 & 13 \\
\hline
\end{tabular}

KEY: Aug: augmentin (30 $\mu \mathrm{g})$

Ery: Erythromycin $(5 \mu \mathrm{g})$

Cxc: Cloxacillin $(10 \mu \mathrm{g})$

Cot: $=$ Cotrimoxazole $(10 \mu \mathrm{g})$
Amx = amoxicillin $(25 \mu \mathrm{g})$.

Tet $=$ Tetracycline $(10 \mu \mathrm{g})$

Gen $=$ Gentamicin $(10 \mu \mathrm{g})$

$\mathrm{ChI}=$ Chloramphenicol $(20 \mu \mathrm{g})$

$*=$ Zone of growth inhibition (Sensitivity) ${ }^{* *}=$ No zone of growth inhibition (resistance). 
TABLE 3: MIC'S OF BRANDS OF AMPICLOX AGAINST CLINICAL AND CONTROL STRAINS OF STAPHYLOCOCCUS AUREUS

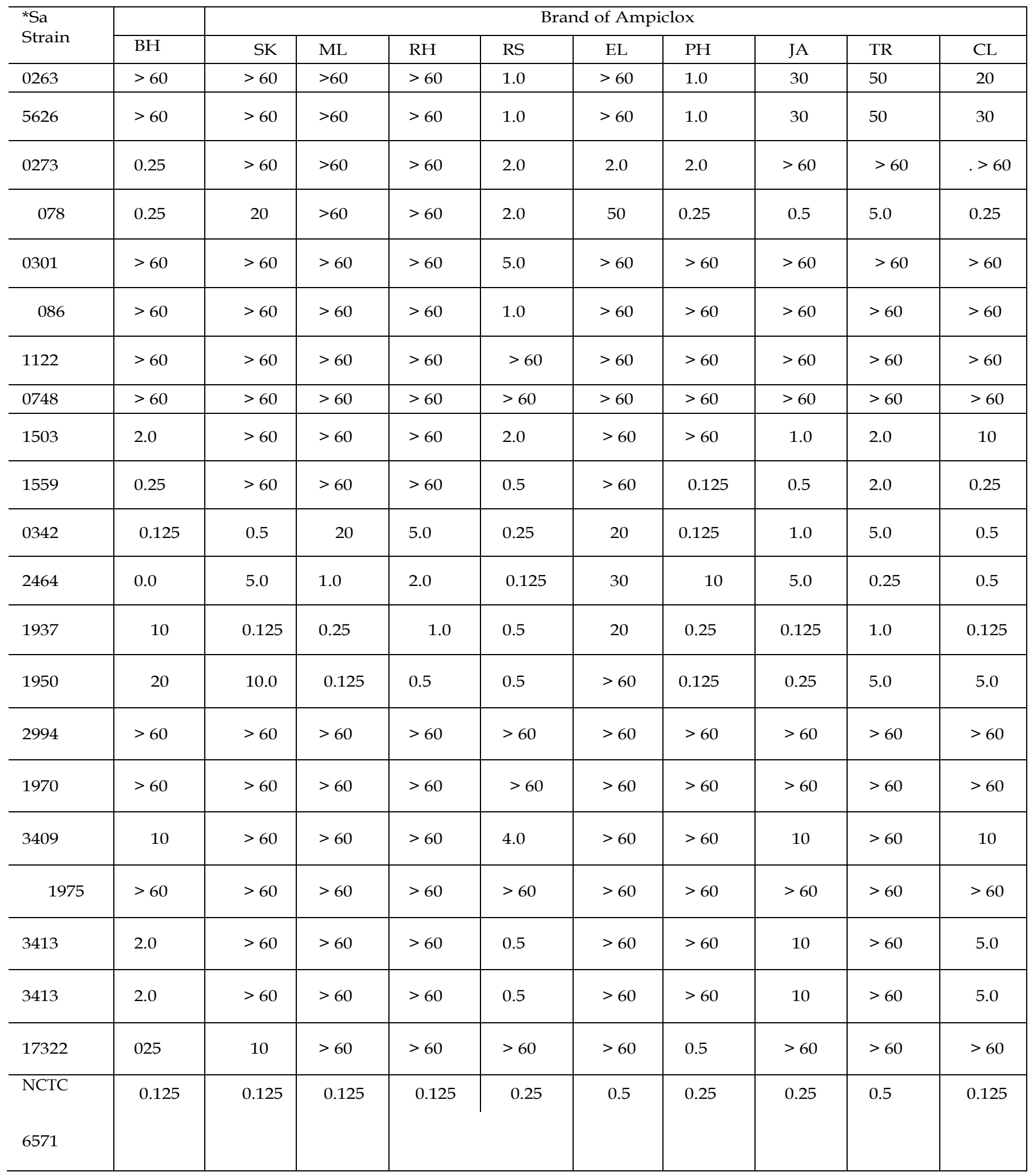

*Stanh-aureus 
TABLE 4: RESISTANCE PATTERN OF THE CLINICAL STRAINS OF STAPH. AURUES AGAINST 10 BRANDS OF AMPICLOX.

$\begin{array}{lcr}\text { Brands of Ampiclox } & \text { No of resistant isolates } & \text { percentage (\%) } \\ \text { BH } & 15 & 75 \\ \text { SK } & 18 & 90 \\ \text { ML } & 18 & 90 \\ \text { RH } & 19 & 95 \\ \text { RS } & 14 & 70 \\ \text { EL } & 20 & 100 \\ \text { PH } & 14 & 70 \\ \text { JA } & 16 & 80 \\ \text { TR } & 19 & 95 \\ \text { CL } & 15 & 75\end{array}$

The variation noted in the activity of 9 out of 10 brands of ampiclox against 9 out 20 clinical strains of Staph aureus and the inactivity of one brand of ampiclox (EL) against none of the 20 clinical strains, corroborates the report of higher demand of one particular brand of ampiclox than the demand for other (19). There is need therefore, for continuous monitoring of the brands of antiobiotics with respect to their activity on relevant bacteria from clinical sources. Having found the control strain, Staph.aureus NCfC 6571, sensitive to the 10 brands of ampiclox tested, the resistance noted in this study among the 20 clinical strains to most of the brands of ampiclox could not be associated with variation in the brands.

\section{REFERENCES}

1. Hugbo P. G. and Ruczaj, Z. (1983). Five decades of BetaIactam antibiotics West Africa. Phamacol. And Drug Res. 6(1) 69 $-93$.

2. Hugo, W. B. and Russell, A. D. (2004). Hugo and Russell's pharmaceutical microbiology $7^{\text {th }}$ edn. Blackwell science Ltd., Blackwell publishing company, oxford, U. K. pp. 481.

3. Washington, J. A. and Sutter, V. L. (1980). Dilution susceptibility test agar and Macrobroth dilution procedures. In: Lenneth, Ballows, A., Hansler, W.J. and Truent, J.P. (eds) Manual of 
Clinical Microbiology, $3^{\mathrm{m}}$ edn. American Society of Micribiology, Washinton D.C. pp.453-458

4. Shanson, D. C. (1986).

Staphylococcal infections in

hospital.

Bri. J. Hosp. Med. 35:312-320.

5. Akinyemi, K. 0, Alabi, S. A., Taiwo, M. A., and Omonigbehin, E. A. (1997) Antimicrobial susceptibility pattern and plasmid profiles of pathogenic bacteria isolated from subjects with urinary tract infections in Lagos, Nigeria.

Nig. Qt. J. Hosp. Med. 7(1): 7-11.

6. Monica, C. (2002). Bacteria pathogens. District laboratory practice in tropical' countries part 2. Cambridge University

Press, Cambridge U. K. pp. 157234.

7. Cleary, T. J. and Maurer. (1978). Methicillin-resistance

Staphylococcus au reus: susceptibility testing by an automated system. Autobac 1 Antimicrob. Agents Chemother. 13 (5): 837841.

8. Allen,J. L. and Cowan, M. E.
(1997). Monitoring outbreaks of methicillin-resistance

Staphylococcus aureus: use of a commercial database and personal compu ter.

Br. J. Biomed. Sci. 54: 10 - 12.

9. Davies, S. (1997). Detection of methicillin- resistance Staphylococcus au reus: the evaluation of rapid agglunation methods. Br. J. Biomed. Sc. 54: 23 $-15$.

10. Tenover, F. C. Biddle, J. W., and Lancaster M. V. (2001). Increasing resistance to Vancomycin and other glycopeptides in Staphylococcus aureus. Emerg. Infect. Dis. 7: 327 -332.

11. Simon,A.E. (2001): Containing Methicillin-Resistance

Staphylococcus aureus: In: Surveillance control and treatment methods. Post grad. Med. 110 (4): 43 - 48.

12. Edine, W. T., Stef L. A. Outi, L., John. D., Paul, S., Nienke, B., Jos, M et al., (2004), Methicillinresistant Staphylococcus aureus in Europe, 1999-2002. Emerg. Infect. Dis. 10 (9): 1627-1634.

13. Kaye, K. S., Gold, H. S., 
Schwaber, M. J., Latta Venkataraman, Youlin Qi, De Girolami P. C., Samore, M. H., Anderson, G., Kamile Rasheed, J. and Tenover, F. C. Variety of (3lactamases produced by Amixicillin-ClavulanateResistant Escherichia coli in the Northeastern United State. Antimicrobial Agents Chemother. 48 (5) 1520 - 1525.

14. Ricki, L. (1995). The risk of antibiotic-resistant infections. In: FDA Consumer Magazine, U. S. Food and Drug Administration.

15. Chigbu,C.O: and Ezeronye O.U. (2003). Antibiotic resistant Staphylococcus aureus in Abia State of Nigeria. Africa Journal of Biotechnology 2 (10): 374 - 378.

16. Klodkowska-farmer, E., ZwolskaKwet, Z., Wojeiechowka, M., Bestty, I, Pacocha, W., Podsiadio, B. and Otto, T. (1995). Pneumonia in patients after extra corporal circulation. Pneumonol Alergo L. 63: 371-377.
17. Lowy, F. D. (1998). Staphylococcus aureus infections N. Engl. J. Med. 339: 520-532.

18. Levy, S. B. (1998). Antimicrobial resistance. In: Bacteria on the defence. Bri. Med. Journal. 371: $612-613$.

19. Omotayo, B. O. (2005). Industrial Training Work Report in the Faculty of Pharmacy University of Ibadan, Ibadan, Nigeria pp. 56. 20.Nester, W. E., Roberts, C. E., Pearsa1, N. N., Anderson, D. G. and Nester, M. T. (1998). Microbiology: A human perspective, $2^{\text {nd }}$ end. The McGraw-Hill companies, inc., U. S. A. pp. $460-656$.

21. Singleton, P. (1999): BACTERRIA. In Biology Biotechnology and Medicine $4^{\text {th }}$ end. John Wiley \& Sons Ltd. Chichester. New York. Weinheim. Brisbane. Singapore. Toronto. Pp.333 - 335. 